\title{
An Empirical Examination of Green Star Certification Uptake and Its Relationship with BIM Adoption in New Zealand
}

\author{
Abstract \\ Purpose \\ Green BIM has been highlighted as an essential topic owing to its potential benefits. However, \\ both Green Star and BIM are still in their earlier stages in New Zealand. This research aims to \\ examine and evaluate the benefits, barriers/challenges, and solutions for the integration of \\ Green Star and BIM in New Zealand.

\section{Design/methodology/approach}

Seventy-seven responses collected from construction professionals in New Zealand using questionnaires were analysed through descriptive and statistical tests

\section{Findings}

Building performance modellings used for Green Star assessment can be implemented using BIM; this was highlighted as the most significant benefit of the integration. Whereas, the most significant barrier preventing the integration of Green Star and BIM was the fact they are two completely separate processes. Regarding the solutions for the integration, showcasing BIMGreen Star benchmark projects was considered as the most effective solution amongst a range of eight provided.

\section{Originality/value}

The research provided insights into Green Star and BIM integration in New Zealand. By evaluating the significance of the benefits, barriers/challenges, and solutions for the integration, this research could be used as a guideline for Green Star and BIM development by New Zealand Green Building Council (NZGBC), the government, and construction practitioners in New Zealand. Specifically, the results here could be valuable inputs for Green Star manuals and the New Zealand BIM handbook. 
Keywords: Green Star; green rating systems, BIM, green BIM, New Zealand Green Building Council (NZGBC); New Zealand

\section{Introduction}

The construction industry has been criticised due to its adverse impacts causing environmental degradation, carbon emissions, and global warming (Suzer, 2015). Green building has emerged as a key topic in the construction field to mitigate the current problem of the building sector (Doan et al., 2017). Also, hundreds of green rating systems have been developed to reduce the negative impacts of construction projects on the environment (Vierra, 2016). Green Star New Zealand, established by the New Zealand Green Building Council (NZGBC), is one of the internationally-recognised rating systems to promote the sustainability of construction projects (NZGBC, 2020). However, only 254 construction projects were certified as Green Star projects during 2007 and 2019, a modest number of Green Star certified projects (NZGBC, 2021).

One of the reasons explaining the low uptake of Green Star in New Zealand could be a lack of understanding (Doan et al., 2019). Also, Green Star has not been an attractive topic to the researchers in New Zealand, with very few publications. Amongst three journal articles focusing on Green Star conducted by other researchers, two of them examined the Indoor Environment Quality (IEQ) (Byrd and Rasheed, 2016, Rasheed et al., 2017), a significant category amongst nine categories required for the assessment by NZGBC. Whereas, whether the cost of green buildings is higher than conventional buildings was investigated by Rehm and Ade (2013).

It is noticed that green BIM has caught researchers' attention recently. The integration of BIM and LEED (Leadership in Energy and Environmental Design) is expected to support the designers during the design stage to be more productive (Jalaei and Jrade, 2015). Also, BREEAM (Building Research Establishment Assessment Method)-BIM was researched to produce an automatic sustainability assessment (Ilhan and Yaman, 2016).

However, there is no research exploring the current practice of Green Star and Green Star and BIM integration in New Zealand except for Doan et al. (2019) research. Although benefits, barriers/challenges, and solutions for Green Star uptake and the integration with BIM were provided by Doan et al. (2019), a further validation stage is necessary to confirm the results. This is because the snowball sampling method used in that research could be susceptible to selection bias (Kalton and Graham, 1983, Wheeler et al., 2014). Furthermore, the adopted triangulation method may not be entirely appropriate because literature from other green rating systems was used to validate the results from the research. 
This research aims to validate the results of the Green Star uptake and its relationship with BIM adoption in New Zealand, revealed by Doan et al. (2019). By examining the perspectives of the construction practitioners in New Zealand, the research could provide insights into Green Star uptake. Findings of the research could be used as a guideline for NZGBC and construction companies in New Zealand to have effective strategies to achieve the potential benefits of Green Star uptake.

\section{Green BIM}

Green BIM has been focused by researchers recently due to its potential benefits in various areas (Jalaei and Jrade, 2015, Wong and Kuan, 2014, Azhar and Brown, 2009). The feasibility of integrating either LEED or BREEAM, the most popular green rating systems globally, with BIM has been investigated. After reviewing 400 studies related to this topic, Lu et al. (2017) stated that the management efficiency and success rate of applications could be increased while the cost of green building registration could be reduced with BIM implementation (Lu et al., 2017). According to Jalaei and Jrade (2015), LEEDBIM assists the designer process, leading to an increase in design efficiency. Also, credits of green rating systems could be integrated with BIM for automatic assessment, which was mentioned in the current literature. A method that can partially automate the process of LEED and BIM was suggested by Jalaei and Jrade (2014). LEED was also focused by Nguyen et al. (2015) with the assistance of BIM to produce an automatic LEED score report. Similarly, automatic sustainability assessment can also be achieved when BIM is integrated with BREEAM (Ilhan and Yaman, 2016). Whereas, Chen and Hsieh (2013) developed a BIM-assisted rule-based approach to examine the green building design automatically.

Park et al. (2012) stated that BIM implementation could increase the speed and accuracy of the energy assessment. The use of BIM for energy analysis for passing the performance criteria of LEED or BREEAM was suggested by Motawa and Carter (2013). Half of the Energy and Atmosphere credits in LEED could be utilised with the BIM application (Wu and Issa, 2014). Azhar et al. (2009) mentioned the BIM application on LEED Daylight credit. Azhar and Brown (2009) revealed that LEED documentation was prepared as part of the BIM-based performance analyses by half of the construction professionals working in the US.

Amongst hundreds of green rating systems established globally, only LEED and BREEAM are the main focus on the integration. Other ratings, such as Green Star or CASBEE, should be researched as well because there are differences regarding the characteristics and context of each rating system. In other words, the results of LEED-BIM or BREEAM-BIM may be not applicable to the other green BIM. It is also noticed that the results of the integration shown in previous research are still limited. Only 5 LEED credits were examined with the use of BIM by Azhar et al. (2011) while only 26 BEAM plus credits amongst a total of 80 credits could be achieved with BIM implementation in Wong and Kuan 
(2014) research. Therefore, further research into the challenges and solutions for green BIM implementation should be conducted to achieve the potential benefits of the integration.

In New Zealand, both Green Star and BIM are still in their early stages (Doan et al., 2017, Doan et al., 2020). Specifically, only three journal articles about Green Star and two journal articles about BIM in the New Zealand context could be found on the Scopus database (not including own authors' articles). These indicate the need for further research on these topics to explore Green Star uptake and BIM implementation along with the integration between them. Besides providing the guidelines for Green Star and BIM development in New Zealand, the results of this research could offer learning lessons for the other green rating systems, which has been neglected by academia. Also, it provides insights into green BIM, in which Green Star represents for the other ratings to be examined its relationship with BIM.

\section{Research Methodology}

Questionnaire was adopted as the primary data collection instrument. Its purpose is to generalise and to promote the confidence of the findings in Doan et al. (2019) research. In Doan et al. (2019) research, the qualitative approach, using $21 \mathrm{semi}$-structured interviews, was adopted to examine the perspectives of construction professionals towards Green Star uptake and its relationship with BIM in New Zealand. Although the qualitative method provides "deep, rich observational data," "the virtues of hard, generalisable survey data" could be generally offered by the quantitative one (Onwuegbuzie and Leech, 2005, Sieber, 1973). In other words, the quantitative method is considered appropriate in this research to add rigour to the qualitative approach used in Doan et al. (2019) research (Amaratunga et al., 2002, Johnson and Onwuegbuzie, 2004). Construction professionals' perspectives towards Green Star uptake and its relationship with BIM in New Zealand were found out using sequential explanatory design. This mixed-method has "the potential to provide new insights into, and enhanced understanding of phenomena being investigated ... providing rich data, lead to new lines of thinking, and by intentionally engaging multiple perspectives and presenting a greater diversity of views" (Krivokapic-Skoko and O'neill, 2011).

\subsection{Questionnaire design}

The questionnaire comprised three main sections, including demographics, Green Star uptake and BIM and Green Star integration. There are three themes investigated for Green Star uptake. These are the benefits of Green Star certification uptake, the barriers/challenges to Green Star certification uptake, and solutions for Green Star certification uptake. The themes chosen for BIM and Green Star integration were the benefits of Green Star and BIM integration, the barriers/challenges to Green Star and BIM integration, and the solutions for Green Star and BIM integration. 
Demographic data collected included the respondents' positions in their companies, their companies' sizes, and their types of companies. It went on to establish their experience in the New Zealand construction industry. It examined the number of Green Star and BIM projects they have been involved in, and the highest BIM maturity levels and LODs (level of development) in their BIM projects.

Table 1 and Table 2 summarise the results in Doan et al. (2019) research regarding the benefits, barriers/challenges and solutions for Green Star uptake as well as the perspectives towards Green Star and BIM integration in New Zealand. 
Table 1. Benefits, barriers/challenges, and solutions for Green Star uptake

\begin{tabular}{|c|c|}
\hline Benefits of Green Star certification uptake & Code \\
\hline $\begin{array}{l}\text { The Green Star certified project reduces the environmental impact of the construction } \\
\text { industry. }\end{array}$ & BE1 \\
\hline The Green Star certified project provides a healthy place for end-users. & BE2 \\
\hline The Green Star certified project saves operation costs for end-users. & BE3 \\
\hline $\begin{array}{l}\text { The Green Star certified project is generally sold for a higher price compared to the non- } \\
\text { certified project. }\end{array}$ & BE4 \\
\hline The Green Star certification is a marketing tool to attract end-users. & BE5 \\
\hline The Green Star certification raises the social conscience of sustainable construction. & BE6 \\
\hline $\begin{array}{l}\text { The Green Star certification is a benchmarking system for the design for better building } \\
\text { performance modellings (e.g., energy, lighting). }\end{array}$ & BE7 \\
\hline Barriers/challenges to Green Star certification uptake & Code \\
\hline Perception of the cost of investing in the Green Star certification. & BA1 \\
\hline Lack of understanding of the Green Star benefits. & BA2 \\
\hline $\begin{array}{l}\text { Lack of benchmark projects which can showcase the benefits of the Green Star } \\
\text { certification. }\end{array}$ & BA3 \\
\hline Lack of client demand for the Green Star certification uptake. & BA4 \\
\hline The complex administration process of the Green Star certification uptake. & BA5 \\
\hline Solutions for Green Star certification uptake & Code \\
\hline Clients should be educated about the benefits of Green Star certification. & SO1 \\
\hline Benchmark Green Star projects should be showcased widely. & $\mathrm{SO} 2$ \\
\hline Incentives (e.g., tax reduction) should be provided for Green Star certified projects. & $\mathrm{SO} 3$ \\
\hline $\begin{array}{l}\text { The Green Star process should be optimised to simplify the administration of getting } \\
\text { Green Star certification. }\end{array}$ & $\mathrm{SO} 4$ \\
\hline Green Star should be integrated with BIM. & SO5 \\
\hline Green Star registration fees should be reduced from the current level. & SO6 \\
\hline
\end{tabular}


Table 2. Benefits, barriers/challenges, and solutions for Green Star and BIM integration

\begin{tabular}{|c|c|}
\hline Benefits of Green Star and BIM integration & Code \\
\hline $\begin{array}{l}\text { Building performance modellings (e.g., energy, lighting) used for Green Star assessment } \\
\text { can be implemented using BIM. }\end{array}$ & BEI1 \\
\hline $\begin{array}{l}\text { Building models can incorporate all the information (e.g., Building Users' Guide, } \\
\text { Commissioning report) for Green Star assessment of the project. }\end{array}$ & BEI2 \\
\hline Green Star credits can be integrated with BIM for automatic Green Star assessment. & BEI3 \\
\hline Using BIM for Green Star certification uptake can potentially reduce the assessment time. & BEI4 \\
\hline $\begin{array}{l}\text { Green Star certification uptake requires the building performance modellings and related } \\
\text { information, which are the aspects of the BIM process. Therefore, increasing the Green } \\
\text { Star certification uptake can potentially increase the BIM adoption rate. }\end{array}$ & BEI5 \\
\hline Barriers/challenges to Green Star and BIM integration & Code \\
\hline $\begin{array}{l}\text { BIM implementation and Green Star certification have two completely separate } \\
\text { processes. }\end{array}$ & BAI1 \\
\hline Lack of client demand for projects that required both BIM and Green Star. & BAI2 \\
\hline $\begin{array}{l}\text { The New Zealand Green Building Council requires only } 2 \mathrm{D} \text { documents for the } \\
\text { assessment process rather than a full BIM model. }\end{array}$ & BAI3 \\
\hline BIM maturity level in New Zealand is currently low. & BAI4 \\
\hline LOD in New Zealand is currently low. & BAI5 \\
\hline Lack of understanding on the positive potentials of integrating BIM with Green Star. & BAI6 \\
\hline Solutions for Green Star and BIM integration & Code \\
\hline $\begin{array}{l}\text { Clients and stakeholders should be educated on both BIM implementation and Green Star } \\
\text { certification processes. }\end{array}$ & SOI1 \\
\hline The Green Star certification and BIM implementation processes should be integrated. & SOI2 \\
\hline $\begin{array}{l}\text { The New Zealand Green Building Council should change their document requirements to } \\
\text { reflect BIM adoption. }\end{array}$ & SOI3 \\
\hline $\begin{array}{l}\text { BIM should be executed properly first (the BIM maturity level and LOD have to be high } \\
\text { enough) before the integration with Green Star. }\end{array}$ & SOI4 \\
\hline $\begin{array}{l}\text { Green Building Council should work with construction stakeholders to optimise the } \\
\text { Green Star certification process. }\end{array}$ & SOI5 \\
\hline A Green Star material database should be created for BIM integration. & SOI6 \\
\hline Benchmark projects based on BIM-Green Star integration should be showcased widely. & SOI7 \\
\hline $\begin{array}{l}\text { BIM implementation should be mandated in New Zealand for certain types of projects } \\
\text { (e.g., public projects). }\end{array}$ & SOI8 \\
\hline
\end{tabular}

Except the demographics part, a five-point Likert scale was used in the questionnaire, where $1=$ Strongly Disagree; 2 = Slightly Disagree; 3 = Neutral; 4 = Slightly Agree; 5 = Strongly Agree. For Agree and Disagree scales, Revilla et al. (2014) recommended the five answer categories rather than others providing better quality for collected data. 


\subsection{Sampling}

The criteria used to select the appropriate respondents was based on their experience. The questionnaire was distributed to construction professionals having at least three years' experience in the New Zealand construction industry. Also, participating in at least one Green Star or one BIM project was essential. Because Green Star and BIM are still in their early stages in New Zealand (Doan et al., 2019), there may be a limited number of respondents satisfying the mentioned criteria. Therefore, a mixed sampling technique was adopted to increase the number of participants, which is a common technique in quantitative studies (Teddlie and $\mathrm{Yu}, 2007$ ). Both random sampling and purposive sampling were adopted in this research. The random sampling ensures that "each individual in the population has an equal probability of being selected" (Creswell and Creswell, 2017), which "provides the ability to generalise to a population" (Creswell and Creswell, 2017). Whereas, the purposive sampling ensures the correctness of the data owing to the expertise of the participants (Teddlie and Yu, 2007).

The questionnaire was developed on Qualtrics which was then self-administered via Green Star and BIM groups on LinkedIn. Also, potential respondents were invited to participate in the research using contacts obtained from the NZGBC and the Architectural Designers New Zealand (ADNZ) database.

Before distributing the questionnaire, the pilot testing was conducted by inviting 21 construction professionals to check the research instrument. The purpose of this step is to avoid the misinterpretation of the questions and to check the time taken to complete the questionnaire, wording, layout, and ordering of the questions (Grimm, 2010). The final questionnaire was revised based on their suggestions.

After two months of distributing the questionnaire, 166 construction professionals accessed the questionnaire link amongst 403 invitations. However, only 85 participants completed the Green Star part in which the statements regarding the benefits, barriers/challenges, and solutions for Green Star uptake in New Zealand were answered. Whereas, 77 responses were received for the BIM and Green Star integration part. The response rate for Green Star uptake and Green Star and BIM integration is $21 \%$ and $19.1 \%$ respectively, considered as a usual rate for the questionnaire (Akintoye, 2000, Oke and Aghimien, 2018).

\subsection{Analysis}

The questionnaire data was analysed using both descriptive and statistical tests with the aid of the Statistical Package for the Social Sciences (SPSS) version 24. The one-sample $t$-test was adopted to determine the significance of the statements. In other words, all the statements in Tables 1 and 2 were analysed with the one-sample $t$-test to consider their appropriateness in the New Zealand context. The one-sample t-test was used in this research because it indicates the difference between the statement means and the test values (Dinh, 2020). Specifically, the test aims to reject the null hypothesis that the means of the benefits, barriers/challenges, and solutions for Green Star and BIM and Green Star 
integration are not significantly different from the test value with $p$-value $<0.05$. With the five-point Likert scale, the test value of 3.0 is considered appropriate for the one-sample $t$-test (Kavishe $e t$ al., 2018, Hwang et al., 2014). Whereas, Owusu-Manu et al. (2018) and Manu et al. (2018) suggested testing the mean score with the test value of 3.5 in the five-point Likert scale. Consequently, the onesample $t$-test was conducted in 2 rounds, with the test values of 3.5 and 3.0.

Although no minimum sample size is required for the one-sample $t$-test (Kavishe et al., 2018), a comparison with other studies regarding the sample size was also carried out. The sample sizes in this research are appropriate compared to 45 of Robert et al. (2014), 34 of Cheung et al. (2012), and 28 of Kavishe et al. (2018) research.

To ensure the correctness of the results, the normal distribution of the data was checked before going through the one-sample $t$-test (Ross and Willson, 2018). According to Field (2013), the normality of the data could be spotted by calculating the values of skewness and kurtosis. All the statements have the values of skewness within the range \pm 2 and \pm 3 for the values of kurtosis proving the normality of the data (Griffin and Steinbrecher, 2013, Schneider and Wheeler-Kingshott, 2014).

\section{Results}

Before conducting further analysis, Cronbach's Alpha test was carried out to evaluate the reliability and internal consistency of the collected data. 0.7 was considered as the cut off point for the test by most of the studies (Kavishe et al., 2018, Owusu-Manu et al., 2018). The results for the test in this research are 0.771 for Green Star uptake and 0.84 for BIM and Green Star integration respectively, implying that the data is reliable for further analysis.

\subsection{Demographic information}

The criteria for selecting the respondents were checked to eliminate inappropriate cases. Firstly, the number of Green Star and the number of BIM projects were examined to remove the cases in which the construction professionals have not been involved in any BIM and Green Star projects. Eight cases were removed for the Green Star part, which is the same for BIM and Green Star integration part. Secondly, less than three year's experience in the New Zealand construction industry was checked to ensure that the respondents have perceived specific knowledge in the industry. One case was removed when the respondent only has one year's experience for both the Green Star part and BIM and Green Star integration part. It is noticed that four cases in Green Star part have two years' experience, but they were accepted for the analysis. This is because they proved their experience in this topic by the number of Green Star projects they have been involved in. 
Table 3 shows the characteristics of the respondents participating in this research. Three is the average number of Green Star projects those respondents involved in while thirteen is the average number of BIM projects. Green Star Accredited Professionals (GSAP) account for the significant percentage of the respondents with around $26 \%$, followed by architects and mechanical, electrical, and plumbing (MEP) engineers with $15 \%$ and $14 \%$, respectively. It is noted that a respondent can hold multiple positions at the same time. For example, one respondent is an MEP engineer, a Green Star assessor, and a GSAP while another respondent is a BIM manager, an architect, and a GSAP. Furthermore,

Table 3 shows the number of respondents working in small and medium-sized enterprises (SMEs) and large companies. SMEs are those who have less than 20 employees, defined by the New Zealand Ministries (MBIE, 2017, MED, 2011).

Table 3. Respondents' demographics in Green Star uptake section

\begin{tabular}{ll}
\hline Respondent Role & Frequency $(\%)$ \\
\hline GSAP & $31(26.05 \%)$ \\
Green Star Assessor & $02(01.68 \%)$ \\
Architect & $18(15.13 \%)$ \\
MEP Engineer & $17(14.29 \%)$ \\
Contractor & $08(06.72 \%)$ \\
BIM Manager & $07(05.88 \%)$ \\
Quantity Surveyor & $07(05.88 \%)$ \\
Project Manager & $05(04.20 \%)$ \\
Structural Engineer & $04(03.36 \%)$ \\
Client & $03(02.52 \%)$ \\
Others & $17(14.29 \%)$ \\
\hline Company Size & Frequency $(\%)$ \\
\hline SME & $21(27.63 \%)$ \\
Large company & $55(72.37 \%)$ \\
\hline Experience & $02-13-46 *$ \\
\hline No of Green Star projects & $00-03-35 *(50 * *)$ \\
\hline No of BIM projects & $00-13-100 *(68 * *)$ \\
\hline Min-Averge-Max &
\end{tabular}

*Min-Average-Max

**Number of respondents involving in Green Star/BIM projects

The average experience of the respondents for BIM and Green Star integration section is fourteen years, see Table 4. Three and thirteen are the average numbers of Green Star and BIM projects they have been involved in respectively. Almost all of the respondents have been involved in BIM projects, and over three-quarters of the respondents have practical experience in Green Star. BIM level 2 and LOD 300 
are considered as the average BIM maturity level and LOD in New Zealand, with almost a third of the respondents.

Table 4. Respondents' demographics in BIM and Green Star integration section

\begin{tabular}{|c|c|}
\hline Respondent Role & Frequency $(\%)$ \\
\hline GSAP & $29(26.85 \%)$ \\
\hline Green Star Assessor & $02(01.85 \%)$ \\
\hline Architect & $17(15.74 \%)$ \\
\hline MEP Engineer & $16(14.81 \%)$ \\
\hline BIM Manager & $07(06.48 \%)$ \\
\hline Quantity Surveyor & $06(05.56 \%)$ \\
\hline Contractor & $05(04.63 \%)$ \\
\hline Project Manager & $05(04.63 \%)$ \\
\hline Structural Engineer & $04(03.70 \%)$ \\
\hline Client & $03(02.78 \%)$ \\
\hline Others & $14(12.96 \%)$ \\
\hline Company Size & Frequency $(\%)$ \\
\hline SME & $18(26.47 \%)$ \\
\hline Large company & $50(73.53 \%)$ \\
\hline Experience & $03-14-50 *$ \\
\hline No of Green Star projects & $00-03-35 *(52 * *)$ \\
\hline No of BIM projects & $00-13-100 *\left(65^{* *}\right)$ \\
\hline BIM maturity levels & Frequency $(\%)$ \\
\hline Level 1 & $05(07.69 \%)$ \\
\hline Level 2 & $20(30.77 \%)$ \\
\hline Level 3 & $07(10.77 \%)$ \\
\hline Unsure & $33(50.77 \%)$ \\
\hline LODs & Frequency $(\%)$ \\
\hline 200 & $03(04.62 \%)$ \\
\hline 300 & $19(29.23 \%)$ \\
\hline 350 & $15(23.08 \%)$ \\
\hline 400 & $05(07.69 \%)$ \\
\hline 500 & $04(06.15 \%)$ \\
\hline Unsure & $19(29.23 \%)$ \\
\hline
\end{tabular}

*Min-Average-Max

**Number of respondents involving in Green Star/BIM projects 
Over a quarter of the respondents are GSAP, while two Green Star assessors also participated in the survey. Architects and MEP engineers have similar figures regarding the percentage of the respondents, around $15 \%$. Whereas, the figures for BIM managers, quantity surveyors, contractors, project managers, structural engineers, and clients are not much different from each other ranging from $2.78 \%$ to $6.48 \%$.

Almost three-quarters of the respondents are working in large companies, but there are still a higher number of respondents working in SMEs, with 18 cases. From the demographic information shown in

Table 3 and Table 4, it is reasonable to conclude that the respondents' knowledge is suitable for enhancing the reliability and validity of the research results.

\subsection{Green Star uptake}

\subsubsection{Benefits of Green Star certification uptake}

The data concerning the benefits of Green Star certification uptake were analysed using the one-sample $t$-test. Table 5 shows that BE2 was perceived as the most important benefit of Green Star, followed by BE1. They have the highest mean scores compared to the rest, which was then used to rank the benefits of Green Star. BE7 and BE5 have similar scores, which were ranked $3^{\text {rd }}$ and $4^{\text {th }}$. While $5^{\text {th }}$ and $6^{\text {th }}$ places belong to BE3 and BE6, with almost identical scores. BE4 is the only benefit receiving the mean score close to 4.00, 3.96 .

Table 5. One-sample $t$-test results of the benefits of Green Star certification uptake

\begin{tabular}{cccccccccccc}
\hline & & & & & & & \multicolumn{3}{c}{ One-sample $t$-test (test value $=3.5)$} \\
& & & & & & & & & & \multicolumn{3}{c}{$\begin{array}{c}95 \% \text { confidence } \\
\text { interval of the } \\
\text { difference }\end{array}$} \\
\hline Benefit & Mean & SD & $\begin{array}{c}\text { SE } \\
\text { Mean }\end{array}$ & Rank & $t$ & $d f$ & $\begin{array}{c}\text { Sig. } \\
\text { (2-tailed) }\end{array}$ & $\begin{array}{c}\text { Mean } \\
\text { diff. }\end{array}$ & Lower & Upper \\
\hline BE1 & 4.26 & 0.839 & 0.096 & 2 & 7.934 & 75 & 0.000 & 0.763 & 0.57 & 0.95 \\
BE2 & 4.38 & 0.711 & 0.082 & 1 & 10.806 & 75 & 0.000 & 0.882 & 0.72 & 1.04 \\
BE3 & 4.09 & 0.897 & 0.103 & 5 & 5.754 & 75 & 0.000 & 0.592 & 0.39 & 0.8 \\
BE4 & 3.96 & 0.871 & 0.100 & 7 & 4.610 & 75 & 0.000 & 0.461 & 0.26 & 0.66 \\
BE5 & 4.13 & 0.806 & 0.092 & 4 & 6.834 & 75 & 0.000 & 0.632 & 0.45 & 0.82 \\
BE6 & 4.08 & 0.744 & 0.744 & 6 & 6.783 & 75 & 0.000 & 0.579 & 0.41 & 0.75 \\
BE7 & 4.16 & 0.880 & 0.101 & 3 & 6.516 & 75 & 0.000 & 0.658 & 0.46 & 0.86 \\
\hline
\end{tabular}

All of the standard deviation (SD) values are less than 1, indicating a high consistency in agreement amongst respondents' perspectives. Furthermore, all values of the standard error (SE) mean close to 0, enhancing the reliability and validity of the results. In other words, the mean of the sample is sufficiently 
precise to the true mean of the population. Also, all the $t$-values are positive, and $p$-values are significant, indicating that the means are significantly higher than the test value of 3.5. In other words, the seven benefits of Green Star certification uptake are all important.

\subsubsection{Barriers/challenges to Green Star certification uptake}

Table 6 shows the one-sample $t$-test results of the barriers/challenges to Green Star certification uptake. BA1 and BA4 are the two most significant barriers/challenges to Green Star certification uptake, with the mean scores of 4.36 and 4.29, respectively. The results for BA2 and BA5 are similar with 3.97 and 3.91 mean scores. BA3 is the only barrier having the mean score of less than 3.50 .

Table 6. One-sample $t$-test results of the barriers/challenges to Green Star certification uptake

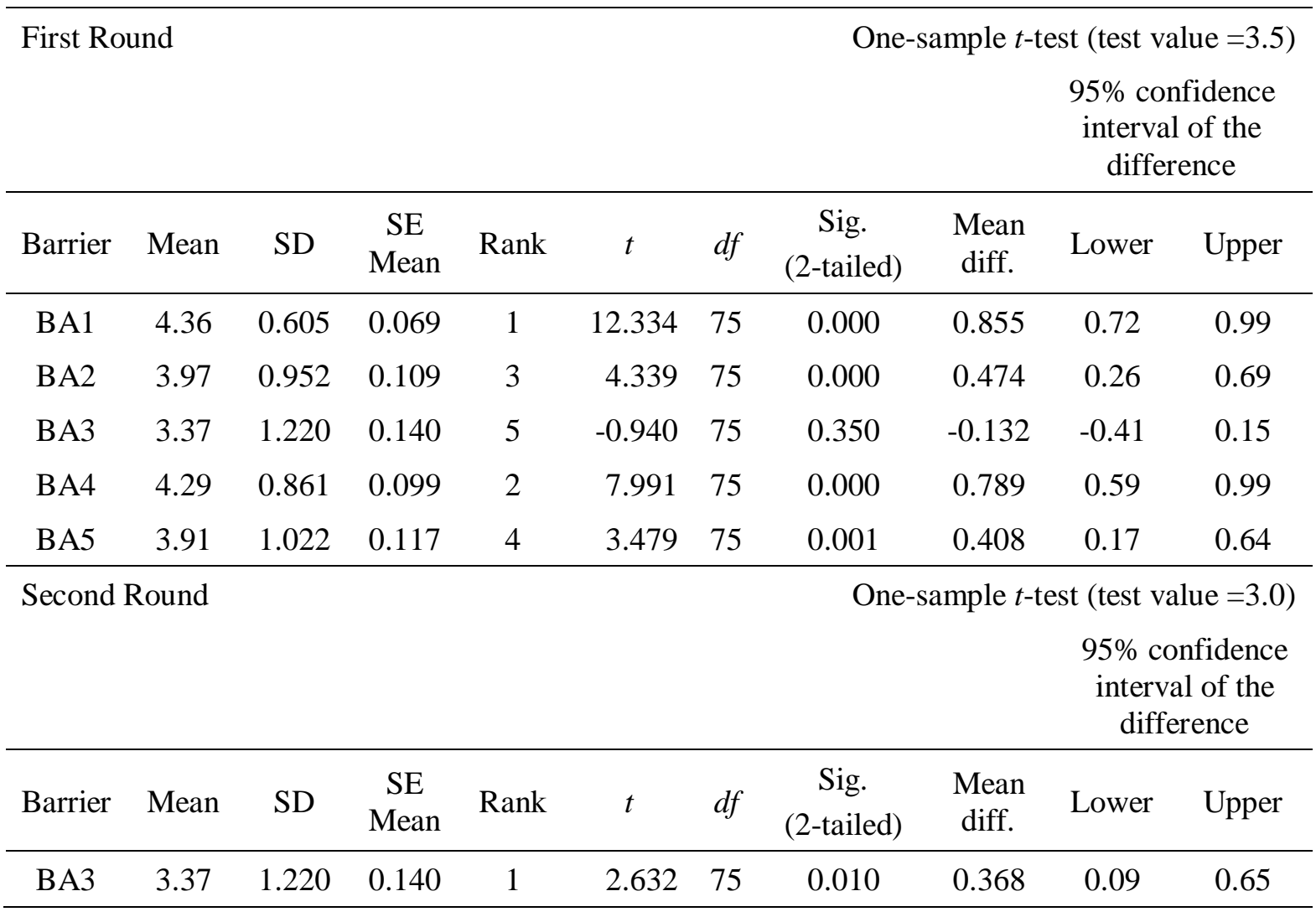

Although the SD values of the barriers/challenges are higher than those of the benefits, the values are less than 2, indicating that the perspectives of the participants are consistent with each other (LabCE, 2019). Whereas, the SE mean values close to 0 promoting the reliability and validity of the data. Except for BA3, all the $t$-values of barriers/challenges to Green Star certification uptake are positive with significant $p$-values to the test value of 3.5. This proves that those barriers/challenges are significant towards Green Star certification uptake. BA3 was then checked with the test value of 3.0 in the second round as Hwang et al. (2014), and Kavishe et al. (2018) stated that 3.0 is still the appropriate test value to examine the significance of the barrier. The results in the second round show that BA3 is still a 
significant barrier/challenge to Green Star certification uptake with positive $t$-value and significant $p$ value to the test value of 3.0.

\subsubsection{Solutions for Green Star certification uptake}

Table 7 shows the results of the one-sample $t$-test for the solutions for Green Star certification uptake. Interestingly, $\mathrm{SO} 2$ was perceived as the most effective solution even though it has the lowest rank in the barriers/challenges to Green Star certification uptake in the previous section. SO1 and SO3 have the same mean score, 4.34. However, the SD value of SO1 less than the one of SO3; they were ranked $2^{\text {nd }}$ and $3^{\text {rd, }}$ respectively. The $4^{\text {th }}$ place belongs to $\mathrm{SO} 4$. SO6 and SO5 are two solutions having the mean scores less than 4.00 .

Table 7. One-sample $t$-test results of the solutions for Green Star certification uptake

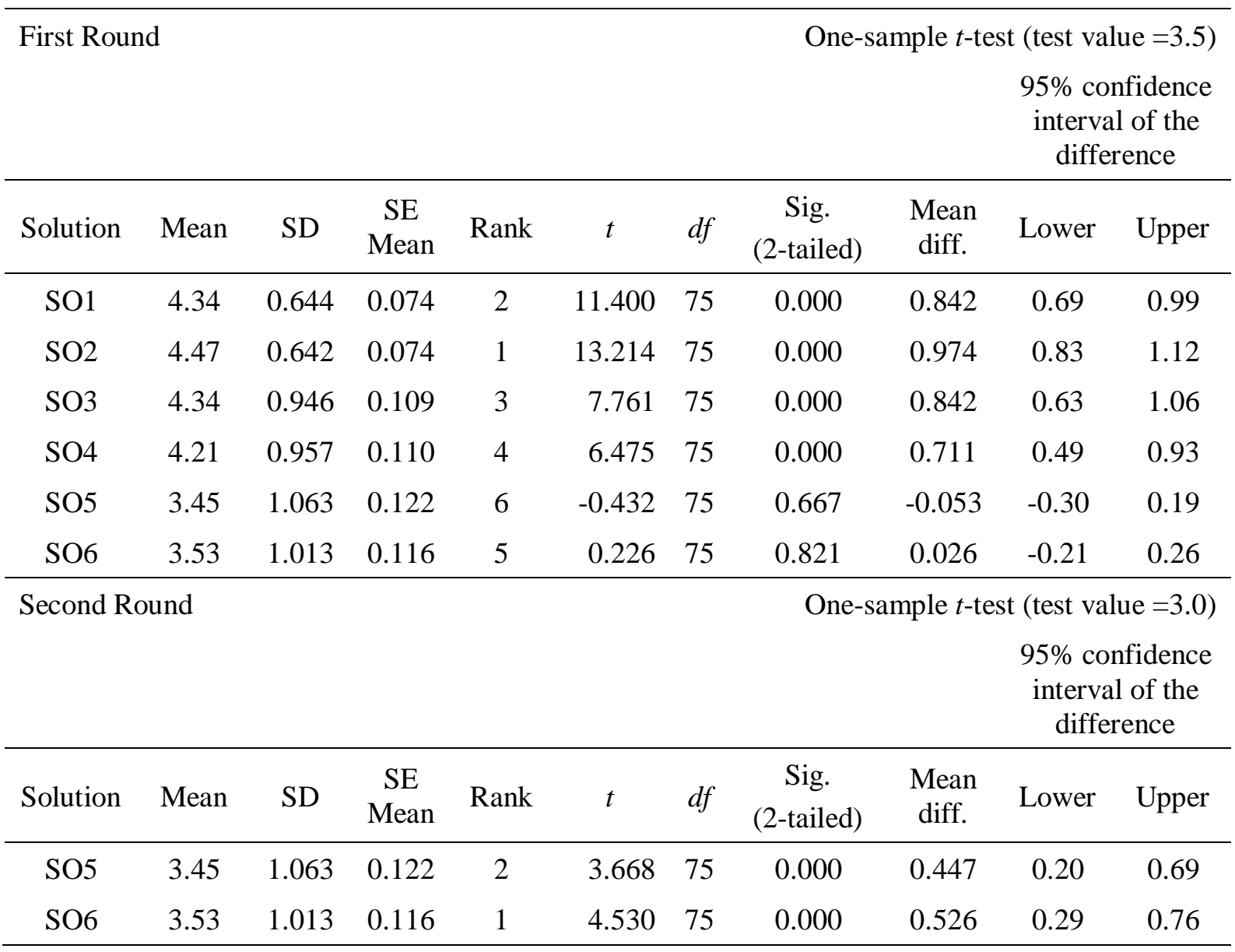

All the SD values close to 1 and the SE mean values close to 0 , implying the reliability and validity of the data. SO5 is the only solution having a negative $t$-value, while the $p$-value of SO6 is not significant. They were then analysed in the second round with the test value of 3.0 to consider their significance as the solutions for Green Star development. In other words, the other four solutions are considered effective and should be followed to improve the number of Green Star certified projects. The results of 
SO5 and SO6 in the second round shows that they have positives $t$-values with significant $p$-values suggesting the positive impacts of these two solutions on Green Star certification uptake.

\subsection{BIM and Green Star integration uptake}

\subsubsection{Benefits of BIM and Green Star integration}

The results of the one-sample $t$-test for the benefits of Green Star and BIM integration are shown in Table 8. BEI1 and BEI2 are two benefits having the highest mean scores, 3.93 and 3.79 respectively, which were ranked $1^{\text {st }}$ and $2^{\text {nd }}$. BEI4 has a mean score of just over 3.50 , holding the $3^{\text {rd }}$ place, while both BEI3 and BEI5 have the mean scores below 3.50, ranked $4^{\text {th }}$ and $5^{\text {th }}$. All the values of SD of five benefits are less than 1 , while the values of SE mean close to 0 , indicating the reliability and validity of the data collected.

Table 8. One-sample $t$-test results of the benefits of Green Star and BIM integration

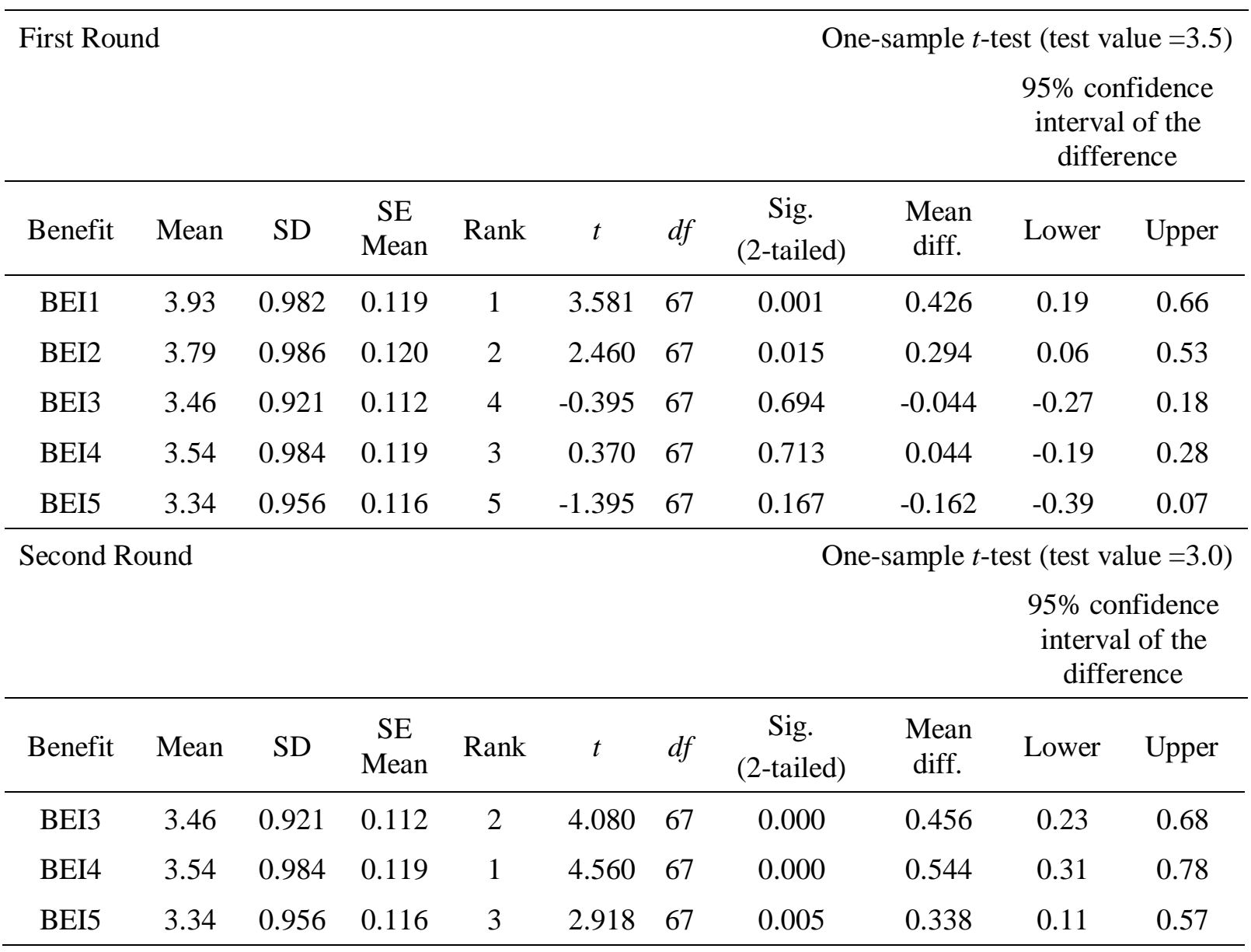

It is clear from Table 8 that BEI1 and BEI2 are the two most perceived benefits from the respondents, with positive $t$-values and $p$-values $<0.05$. Although BEI4 has the $t$-value $>0$, its $p$-value $=0.713>$ 0.05. Because the mean values of BEI3 and BEI5 are less than 3.50, they have negative $t$-values when the one-sample $t$-test was conducted with the test value equal to 3.5. As a result, BEI3-5 were analysed in the second round with the test value 3.0 to consider the importance of these three benefits. 
The results in the second round indicate the importance of BEI3-5 to the test value of 3.0 with positive $t$-values and all $p$-values $<0.05$. In conclusion, all the five mentioned benefits were well-perceived from the respondents.

\subsubsection{Barriers/challenges to BIM and Green Star integration}

The results of the one-sample $t$-test of the barriers/challenges to Green Star and BIM integration are shown in Table 9. Interestingly, BAI1 and BAI4 have the same mean score, 4.06. However, the SD value of BAI1 is less than the one of BAI4; BAI1 was then ranked $1^{\text {st }}$ as the most significant barrier/challenge to Green Star and BIM integration. BAI6 holds the $3^{\text {rd }}$ place with a similar mean score, 4.04. The $4^{\text {th }}$ place belongs to BAI2 with a mean score of 3.87 while BAI3 and BAI5 share the lowest ranks with the mean scores of 3.72 and 3.63, respectively. All the SD values close to 1, along with the SE means close to 0 prove the reliability and validity of the collected data.

Table 9. One-sample $t$-test results of the barriers/challenges to Green Star and BIM integration

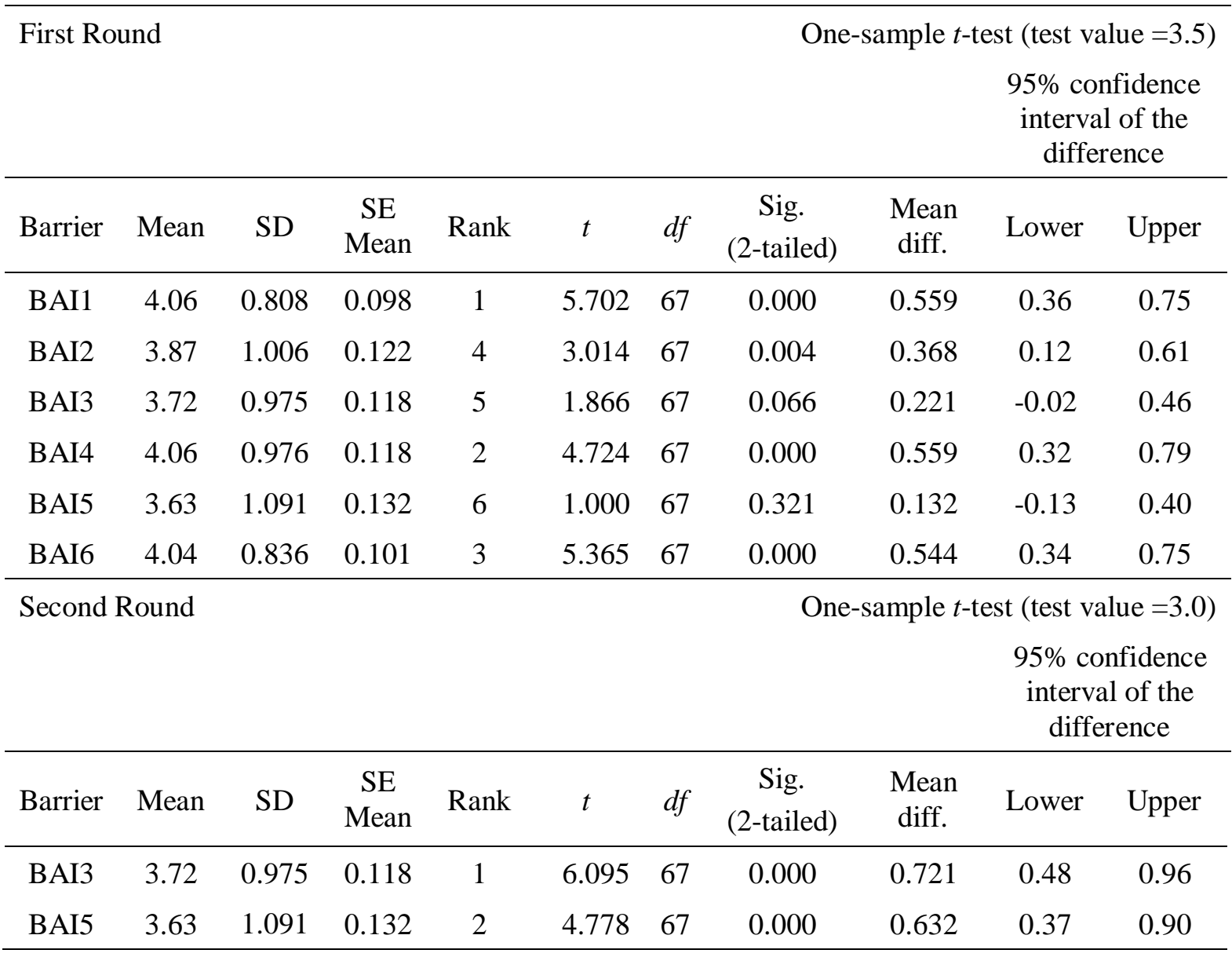

All the $t$-values for six barriers are positive, but the $p$-values for BAI3 and BAI5 are not statistically significant, $p$-values $>0.05$. Therefore, BAI3 and BAI5 were analysed with the test value of 3.0 in the second round to check their significance. The results indicate the significance of the BAI3 and BAI5 
with positive $t$-values and $p$-values $<0.05$. In conclusion, Green Star and BIM have entirely separate processes, BAI1, is the most significant barrier. Whereas, low LOD in BIM adoption, BAI5, has the lowest rank regarding the barriers/challenges to Green Star and BIM integration compared to five other barriers/challenges.

\subsubsection{Solutions for BIM and Green Star integration}

Table 10 shows the results of the one-sample $t$-test for the solutions for Green Star and BIM integration in New Zealand. SOI5 is considered as the best solution with the highest mean score, 4.28 , followed by SOI7 with a mean score of 4.26. SOI6 and SOI7 are the two solutions left with the mean scores higher than $4.00,4.16$ and 4.10 respectively. SOI 4 and SOI8 share similar mean scores, 3.79 and 3.78 . The $7^{\text {th }}$ place belongs to SOI3 with 3.40 mean score while SOI2 holds the lowest rank with 3.35 mean score. The values for SD and SE mean of all eight solutions close to 1 and 0 respectively implying the reliability and validity of the collected data. 
Table 10. One-sample $t$-test results of the solutions for Green Star and BIM integration

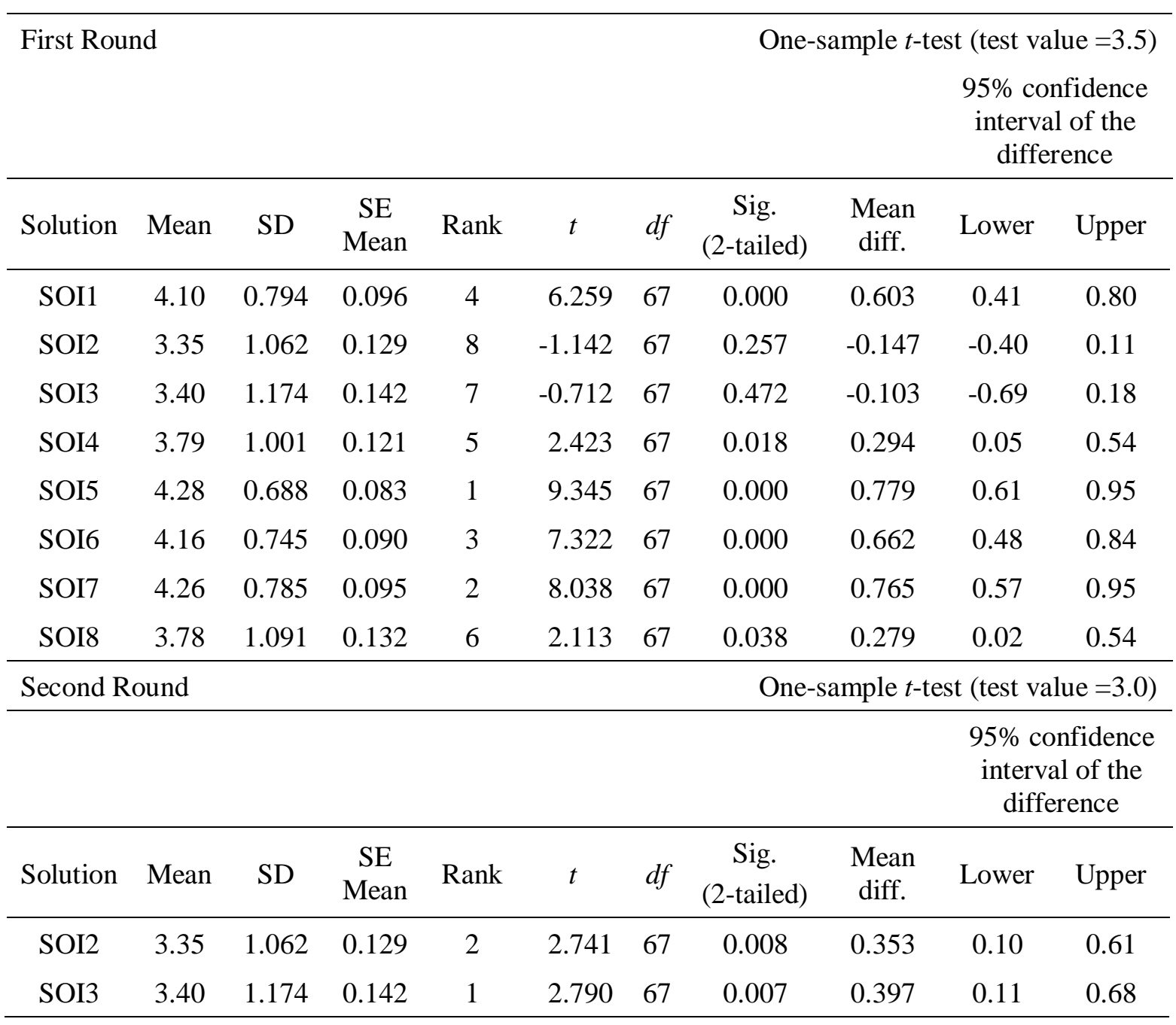

Except for SOI2 and SOI3, all the solutions have positive $t$-values and $p$-values $<0.05$ indicating the effectiveness of the mentioned solutions. After analysing SOI2 and SOI3 with the test value of 3.0 in the second round of the one-sample $t$-test, the results indicate the significance of the solutions SOI2 and SOI 3 with $t$-values $>2$ and $p$-values $<0.05$.

\section{Discussion}

Figure 1 summarises the results of this research. The findings align with existing literature. King (2017) stated that green-certified buildings could provide a sustainable and healthy place for building occupants. Furthermore, green rating systems have been used as benchmarking systems for the design. Pilechiha et al. (2020) indicated the positive relationship between sustainable certification systems and energy performance, a favourite topic recently with a wide range of research (Seyedzadeh et al., 2020b, Seyedzadeh et al., 2020a, Asadi et al., 2012). Specifically, LEED has been used in the US to "provide a benchmarking system to assess levels of sustainability achieved by a building" (Krishnamurti et al., 
2010). Whereas, Green Star (Australia) has been adopted as a benchmarking system to measure the energy efficiency of a project ( $\mathrm{Ng}$ et al., 2013).

Green Star Uptake and Its Relationship with BIM adoption in New Zealand

\begin{tabular}{|c|c|c|}
\hline & Green Star Uptake & \\
\hline \multicolumn{3}{|r|}{ c) Green Star Solutions } \\
\hline$\downarrow$ & $\downarrow$ & $\downarrow$ \\
\hline 1) Providing Healthy Places & 1) Cost Perception & 1) Showcaseing Benchmark Projects \\
\hline 2) Reducing Environmental Impacts & 2) Lack of Client Demand & 2) Providing Education \\
\hline 3) Being a Benchmarking System & 3) Lack of Understanding & 3) Providing Incentives \\
\hline 4) Being a Marketing Tool & 4) Complex Administration & 4) Otimising Administration \\
\hline 5) Saving Operation Costs & 5) Lack of Benchmark Projects & 5) Reducing Registration Fees \\
\hline 6) Rasing Social Conscience & & 6) Integrating with BIM \\
\hline \multicolumn{3}{|l|}{ 7) Higher Selling Prices } \\
\hline & BIM and Green Star Integration & \\
\hline \multicolumn{3}{|l|}{ a) BIM \& Green Star Integration Benefits } \\
\hline$\downarrow$ & $\downarrow$ & $\downarrow$ \\
\hline 1) Using Same Building Permormance Modellings & 1) Two Different Processes & 1) Collaborating between Construction Stakeholders \\
\hline 2) Using same Buildings Models (all information) & 2) Low BIM Maturity Level & 2) Showcaseing Benchmark Projects \\
\hline 3) Reducing Green Star Assessment Time & 3) Lack of Understanding & 3) Providing Green Star Material Database \\
\hline 4) Automatic Green Star Assessment & 4) Lack of Client Demand & 4) Providing Education \\
\hline \multirow[t]{3}{*}{ 5) Increasing BIM adoption rate } & 5) Green Star Submission Requirement & 5) Excecuting BIM correctly \\
\hline & 6) Low LOD & 6) Mandating BIM \\
\hline & & $\begin{array}{l}\text { 7) Changing Green Star Submission Requirements } \\
\text { 8) Integrating the Processes }\end{array}$ \\
\hline
\end{tabular}

Figure 1. Green Star and BIM relationship

The benefit of green rating systems as a marketing tool to attract end-users was also mentioned in the literature. Fuerst and McAllister (2011) revealed that one of the benefits of LEED is a marketing benefit. Whereas, Byrd and Leardini (2011) highlighted the benefit of LEED is "for commercial marketing and promotion rather than for significant environmental concerns." This was also confirmed by Morris $e t$ al. (2018) that the potential of using Green Star (Australia) as a marketing tool was the most perceived benefit by construction professionals. Furthermore, saving operation costs were found out by Kansal and Kadambari (2010). Zuo and Zhao (2014) and Ying Liu et al. (2012) also implied the low operating cost of green buildings.

Regarding the $6^{\text {th }}$ ranking benefit of Green Star, it was confirmed by Kato et al. (2009). Kato et al. (2009) revealed that Green Star (Australia) certified buildings encourage tenants to participate in sustainable events, inspire them to monitor energy and water use, and inspire the staff to be "green people." Higher selling price of Green Star certified projects compared to the non-certified projects is the only benefit having the mean score less than 4.00. Whether a green building has a higher selling price compared to a conventional building is an interesting topic which has been studied by many researchers. Zhang et al. (2018) summarised 18 studies towards the green price premium. Although the results of some studies indicated that the green price premium is positive, others concluded that it is not 
statistically significant. Consequently, the green price premium is still a controversial topic. This is consistent with the results of BE4 having the lowest rank compared to the rest.

Regarding the Green Star barriers/challenges, cost is the most significant barrier to Green Star in Australia (Morris et al., 2018), green buildings in the US (Ahn et al., 2013), and in China (Lam et al., 2009). About the lack of client demand, it was determined as one of the most significant barriers to green buildings in Singapore (Hwang and Tan, 2012) and Malaysia (Samari et al., 2013).

Lack of understanding was ranked first and a foremost barrier to green buildings in Kuwait (AlSanad, 2015) and second in the US (Darko et al., 2017). It is also a common barrier to green buildings in various countries, such as in England (Williams and Dair, 2007), Malaysia (Samari et al., 2013), and Singapore (Hwang and Tan, 2012). Besides, the complexity of the process was considered as one of the three most significant barriers to Green Star in Australia (Morris et al., 2018). It was also determined as a barrier by Darko et al. (2017). Furthermore, the lack of benchmark projects was identified as a barrier to green buildings by Ayarkwa et al. (2017) and Samari et al. (2013). It, however, was ranked in a lower group of the barriers/challenges to green buildings, which is similar to the results of this research.

SO1, SO2, SO3 were not only considered as the most effective solutions for Green Star development in New Zealand, but also they were found out to have significant impacts on sustainable construction in the US (Darko et al., 2017), Singapore (Hwang and Tan, 2012), and Ghana (Ayarkwa et al., 2017). SO4 was also mentioned in Singapore (Hwang and Tan, 2012) and Ghana contexts (Ayarkwa et al., 2017).

SO5 and SO6 were seen as the two less effective solutions compared to the rest in this research. This is reasonable because SO6 was only mentioned in Ayarkwa et al. (2017), one of three recent studies suggesting solutions for green rating systems, including Ayarkwa et al. (2017), Darko et al. (2017), and Hwang and Tan (2012), while SO6 was not mentioned at all in those three studies. However, Lu et al. (2017) summarised the results of 10 studies in green BIM proving the potential of using BIM to support green building assessments.

It is noted that the benefits of using BIM for Green Star certification uptake were more recognised compared to the opposite way in which uptaking Green Star can raise the BIM adoption rate. BEI5, the benefit of using Green Star for increasing BIM adoption rate, has the lowest rank compared to the benefits of using BIM for Green Star certification uptake, including BEI 1-4.

The implementation of BIM for green rating systems certification uptake has been mentioned in previous studies. According to Gandhi and Jupp (2014), 88\% of Green Star (Australia) points could be achieved by implementing BIM. Whereas, GhaffarianHoseini et al. (2017) stated that BIM utilisation 
could help to obtain $75 \%$ of the Green Star criteria. This is consistent with the results of this research, where BEI1 and BEI2 were ranked as the highest benefits regarding the integration of Green Star and BIM.

As mentioned in the Green BIM section, automatic green assessment can be developed with the use of BIM (Jalaei and Jrade, 2014, Chen and Hsieh, 2013, Nguyen et al., 2015). As a result, the assessment time for green building applications can be reduced (Park et al., 2012). These are consistent with the results of BEI3 and BEI4.

Regarding BEI5, it is the new finding of the research focusing on the opposite way in which the Green Star certification uptake could affect the BIM adoption rate. Two-thirds of 21 interviewees in Doan $e t$ al. (2019) research pointed out the impact of Green Star on BIM, which was then proved as a significant benefit of the integration by the respondents participating in the questionnaire in this research.

It is understandable when BAI1 is considered as the most significant barrier. Several studies have been conducted to examine the feasibility of the integration of green rating systems and BIM. Siddiqui et al. (2009) provided insights into the integration of sustainable design solutions and BIM for better sustainable project delivery processes. Whereas, Wong and Kuan (2014) tried offering a solution to streamline the BEAM Plus process to have it integrated with BIM. However, Azhar et al. (2011) concluded that "no one-to-one relationship exists between LEED certification process and BIM-based sustainability analyses" currently even though the potential of the integration was demonstrated. Therefore, combining Green Star and BIM processes should be researched to mitigate the existing problem.

According to the BIM maturity levels adapted by Doan et al. (2020), BIM can only be linked to sustainability once it reaches level 3 or 6D BIM. In other words, high BIM maturity level and high LOD are the prerequisite requirements for the integration. BIM is still encouraged practices in NZ; therefore, it is understandable when low BIM maturity level and LOD were perceived by the respondents in New Zealand. It is also clear from Table 4 that the majority of the construction practitioners in New Zealand are still in BIM level 2 and LOD 300 as the highest BIM maturity level and LOD they achieved.

Lack of BIM understanding was pointed out as a significant barrier to BIM adoption in New Zealand (Doan et al., 2020) while lack of Green Star understanding was determined as a considerable barrier to Green Star uptake in New Zealand (Doan et al., 2019). Therefore, the barrier of lack of understanding of the positive potentials of integrating BIM with Green Star is understandable. In the same vein, lack of client demand for either BIM projects or Green Star projects were identified by Doan et al. (2020) and Doan et al. (2019). As a result, the lack of client demand for projects that required both BIM and Green Star is reasonable. 
Regarding the BAI3, all the requirements for the Green Star assessment could be found out using Green Star Technical Manual v3.1 (NZGBC, 2016). According to the manual, most of the credits could be assessed using short reports and drawings instead of modellings (NZGBC, 2016). Therefore, the Green Star certification seekers are not encouraged to use BIM to bring benefits for both NZGBC and themselves.

Optimising the Green Star process with help from construction stakeholders in the industry, SOI5, was perceived as the most optimal solution for Green Star and BIM integration. This is appropriate due to the current complex administration process of Green Star pointed out in Doan et al. (2019) research, which may prevent Green Star and BIM integration. Besides, the requirements for Green Star assessment should be adjusted to have them linked to BIM adoption, SOI3, and integrating Green Star and BIM processes, SOI2, can provide positive impacts on the integration. Wong and Kuan (2014) indicated the need for a standardised process of the integration of green rating systems and BIM.

Creating a Green Star material database was found out as one of the best solutions for the integration, SOI6, which was also suggested by Seghier et al. (2018) when green BIM papers, focusing mainly on LEED and BREEAM, were reviewed. Providing education, SOI1, and showcasing benchmark projects, SOI7, were suggested as solutions for BIM adoption (Doan et al., 2020) and Green Star certification uptake in New Zealand (Doan et al., 2019). There is no exception for suggested solutions for Green Star and BIM integration; SOI7 is considered as the second most effective solution while the score for SOI1 is not far behind.

As found out in the barriers/challenges to Green Star and BIM integration section that the BIM maturity level and LOD of BIM adoption in New Zealand still need to be higher for better Green Star and BIM integration, suggested by Doan et al. (2020). Therefore, executing BIM properly first is one of the prerequisite factors that should be focused, SOI4. Mandating BIM, SOI8, was revealed as an effective solution for the integration, which was also mentioned by Wu and Issa (2014) and Dummenahally and Glema (2016).

\section{Conclusion and Recommendations}

This research evaluated the significance of the results revealed by Doan et al. (2019) regarding Green Star uptake and its relationship with BIM adoption in New Zealand. Specifically, seven benefits, five barriers/challenges, and six solutions for Green Star uptake along with five benefits, six barriers/challenges, and eight solutions for BIM and Green Star integration were examined. The results indicate that all the findings revealed by Doan et al. (2019) are correct in which all the statements are significant to the test value 3.0 through the one-sample $t$-test. 
All the benefits, barriers/challenges, and solutions were ranked based on their significance. Regarding Green Star uptake, providing a healthy place for end-users, reducing the environmental impact of the construction industry, and being a benchmarking system are the three most benefits perceived by the respondents. Amongst highly ranked barriers/challenges to Green Star certification uptake, perception to cost, lack of client demand, and lack of understanding were the topmost barriers. While the topranked solutions belong to showcasing the benchmark Green Star projects, educating clients on Green Star benefits, and providing incentives for Green Star certified projects.

Towards BIM and Green Star integration, building performance modellings (e.g., energy, lighting) used for Green Star assessment can be implemented using BIM was revealed as the most significant benefit amongst the examined benefits. Followed by the benefit that building models can incorporate all the information (e.g., Building Users' Guide, Commissioning report) for Green Star assessment of the project and the benefit of reducing Green Star assessment time. Regarding the barriers/challenges, having two separate processes is the most considerable one to Green Star and BIM integration. Low BIM maturity level and the lack of understanding are the next two barriers/challenges. To mitigate the existing problems, collaborating between construction stakeholders to optimise the Green Star certification process was implied as the best solution. While showcasing BIM-Green Star benchmark projects and providing Green Star material databases were highlighted as the second and third most effective solutions.

Based on the results of the research, it is recommended that NZGBC should be more active in involving construction stakeholders in registering for Green Star projects. Amongst the five identified barriers for Green Star uptake, understanding is one of the essential factors to the development of Green Star. While the complex administrative process of Green Star and lack of benchmark Green Star projects prevents people from seeking their projects certified. The government/local authorities should also encourage the Green Star practice owing to the determined benefits by providing incentives for Green Star certified projects. For example, 50\% remission of levies to 5 Star or higher Green Star certified projects has been offered by Wellington City Council promoting the development of both Green Star and society towards sustainable development of the country (Doan et al., 2019).

Clients and current practitioners are the key factors affecting the development of Green Star. They should keep updating with green buildings practices to enhance their knowledge to perceive the benefits of Green Star, leading to the involvement in Green Star practices. Although integrating Green Star with BIM was not considered as the leading solution to Green Star development by respondents, many studies proved its effectiveness. Therefore, it is suggested that both NZGBC and construction practitioners examine the possibility of the integration owing to the explored benefits. 
According to the research results of BIM and Green Star integration, it requires effort from not only NZGBC but also both the government and construction practitioners to achieve the potential benefits of Green Star and BIM integration. The NZGBC could work with construction practitioners to streamline the Green Star process, revising the requirements for Green Star assessment, providing Green Star material database, and showcasing the BIM-Green Star benchmark projects. Whereas, the government could mandate BIM to certain types of construction projects to support the integration leading to the benefits to the construction industry and the society.

This research contributes to the current knowledge in two key ways. Firstly, this research provided insights into Green Star uptake and its relationship with BIM adoption in New Zealand. Drivers and challenges to Green Star and its relationship with BIM were identified. To increase the number of Green Star certified projects and BIM adoption rate, solutions to the existing problems were also proposed in this research. Secondly, the characteristics of Green Star were determined and evaluated, which then can be used as guidelines for NZGBC, the government/local authorities, and construction practitioners to have effective strategies towards sustainable development. The results here could be considered for the development of Green Star manuals and the New Zealand BIM handbook.

Because executing BIM correctly was pointed out as an effective solution for the integration, further research will focus on evaluating BIM adoption in New Zealand to consider their readiness for the integration. Specifically, a framework for BIM adoption in New Zealand will be developed to determine the essential factors impacting the success of BIM projects. Based on the information in the framework, BIM practitioners have insights into BIM implementation to plan suitable strategies for projects in order to achieve a higher BIM maturity level and LOD.

\section{Acknowledgements}

The authors are grateful to all of the respondents who participated in this study.

This research has been supported by a Vice-Chancellor Doctoral Scholarship at Auckland University of Technology, New Zealand. 


\section{References}

Ahn, Y. H., Pearce, A. R., Wang, Y. and Wang, G. (2013), "Drivers and barriers of sustainable design and construction: The perception of green building experience", International Journal of Sustainable Building Technology and Urban Development, Vol. 4 No. 1, pp.35-45. doi:10.1080/2093761X.2012.759887.

Akintoye, A. (2000), "Analysis of factors influencing project cost estimating practice", Construction Management \& Economics, Vol. 18 No. 1, pp.77-89. doi:10.1080/014461900370979.

AlSanad, S. (2015), "Awareness, drivers, actions, and barriers of sustainable construction in Kuwait", Procedia Engineering, Vol. 118, pp.969-983. doi:10.1016/j.proeng.2015.08.538.

Amaratunga, D., Baldry, D., Sarshar, M. and Newton, R. (2002), "Quantitative and qualitative research in the built environment: Application of "mixed" research approach", Work Study, Vol. 51 No. 1, pp.17-31. doi:10.1108/00438020210415488.

Asadi, E., da Silva, M. G., Antunes, C. H. and Dias, L. (2012), "A multi-objective optimization model for building retrofit strategies using TRNSYS simulations, GenOpt and MATLAB", Building and Environment, Vol. 56, pp.370-378. doi:10.1016/j.buildenv.2012.04.005.

Ayarkwa, J., Acheampong, A., Wiafe, F. and Boateng, B. (2017), "Factors affecting the implementation of sustainable construction in Ghana: The architect's perspective", 6th International Conference on Infrastructure Development in Africa (ICIDA 2017), 12-14 April 2017, Kumasi, Ghana. Available from: http://ir.knust.edu.gh/xmlui/bitstream/handle/123456789/10851/paper\%2035\%20ICIDA\%202 017\%20CONFERENCE\%20PROCEEDINGS\%20\%202017.pdf?sequence=1, Last Access: 17 August 2021.

Azhar, S. and Brown, J. (2009), "BIM for sustainability analyses", International Journal of Construction Education and Research, Vol. 5 No. 4, pp.276-292. doi:10.1080/15578770903355657.

Azhar, S., Brown, J. and Farooqui, R. (2009), "BIM-based sustainability analysis: An evaluation of building performance analysis software", 45th ASC Annual Conference, 1-4 April 2009, Gainesville, Florida. 276-292. Available from: https://www.researchgate.net/publication/237835268_BIM-

based_Sustainability_Analysis_An_Evaluation_of_Building_Performance_Analysis_Softwar e, Last Access: 17 August 2021.

Azhar, S., Carlton, W. A., Olsen, D. and Ahmad, I. (2011), "Building information modeling for sustainable design and LEED ${ }^{\circledR}$ rating analysis", Automation in Construction, Vol. 20 No. 2, pp.217-224. doi:10.1016/j.autcon.2010.09.019.

Byrd, H. and Leardini, P. (2011), "Green buildings: Issues for New Zealand", Procedia Engineering, Vol. 21, pp.481-488. doi:10.1016/j.proeng.2011.11.2041.

Byrd, H. and Rasheed, E. (2016), "The productivity paradox in green buildings", Sustainability, Vol. 8 No. 4, pp.347. doi:10.3390/su8040347.

Chen, Y. and Hsieh, S. (2013), "A BIM assisted rule based approach for checking of green building design", 13th International Conference on Construction Applications of Virtual Reality (CONVR 2013), 30-31 October 2013, London, UK. Available from: https://itc.scix.net/pdfs/convr-2013-5.pdf, Last Access: 17 August 2021.

Cheung, E., Chan, A. P., Lam, P. T., Chan, D. W. and Ke, Y. (2012), "A comparative study of critical success factors for public private partnerships (PPP) between Mainland China and the Hong Kong Special Administrative Region", Facilities, Vol. 30 No. 13/14, pp.647-666. doi:10.1108/02632771211273132.

Creswell, J. W. and Creswell, J. D. (2017), Research design: Qualitative, quantitative, and mixed methods approaches, Thousand Oaks, CA, US, Sage Publications. ISBN: 1506386717.

Darko, A., Chan, A. P. C., Ameyaw, E. E., He, B.-J. and Olanipekun, A. O. (2017), "Examining issues influencing green building technologies adoption: The United States green building experts' perspectives", Energy and Buildings, Vol. 144, pp.320-332. doi:10.1016/j.enbuild.2017.03.060. 
Dinh, T. S. (2020), "Attitudes of ethnic minorities towards biodiversity conservation in Cat Tien National Park, Vietnam", Journal of Tropical Forest Science, Vol. 32 No. 3, pp.305-310. doi:10.26525/jtfs2020.32.3.305.

Doan, D. T., Ghaffarianhoseini, A., Naismith, N., Ghaffarianhoseini, A., Zhang, T. and Tookey, J. (2019), "Examining Green Star certification uptake and its relationship with Building Information Modelling (BIM) adoption in New Zealand", Journal of Environmental Management, Vol. 250, pp.109508. doi:10.1016/j.jenvman.2019.109508.

Doan, D. T., GhaffarianHoseini, A., Naismith, N., Ghaffarianhoseini, A., Zhang, T. and Tookey, J. (2020), "Examining critical perspectives on Building Information Modelling (BIM) adoption in New Zealand", Smart and Sustainable Built Environment, Vol. ahead-of-print No. ahead-ofprint. doi:10.1108/SASBE-04-2020-0043.

Doan, D. T., Ghaffarianhoseini, A., Naismith, N., Zhang, T., Ghaffarianhoseini, A. and Tookey, J. (2017), "A critical comparison of green building rating systems", Building and Environment, Vol. 123, pp.243-260. doi:10.1016/j.buildenv.2017.07.007.

Dummenahally, N. and Glema, A. (2016), "Green BIM - Eco friendly sustainable design with Building Information Modeling ", International RILEM Conference on Materials, Systems and Structures in Civil Engineering Conference segment on BIM, 22-24 August, 2016, Lyngby, Denmark. Available

from: https://www.researchgate.net/publication/311512193 Green BIM _Eco_Friendly_Sustainable_Design_with_Building_Information_Modeling, Last Access: 17 August 2021.

Field, A. (2013), Discovering statistics using IBM SPSS statistics, Thousand Oaks, CA, US, Sage Publications. ISBN: 1446274586.

Fuerst, F. and McAllister, P. (2011), "Green noise or green value? Measuring the effects of environmental certification on office values", Real Estate Economics, Vol. 39 No. 1, pp.4569. doi:10.1111/j.1540-6229.2010.00286.x.

Gandhi, S. and Jupp, J. (2014), "BIM and Australian Green Star building certification", Computing in Civil and Building Engineering, pp.275-282. doi:10.1061/9780784413616.035.

GhaffarianHoseini, A., Tien Doan, D., Naismith, N., Tookey, J. and GhaffarianHoseini, A. (2017), "Amplifying the practicality of contemporary building information modelling (BIM) implementations for New Zealand green building certification (Green Star)", Engineering, Construction and Architectural Management, Vol. 24 No. 4, pp.696-714. doi:10.1108/ECAM02-2016-0043.

Griffin, M. M. and Steinbrecher, T. D. (2013), "Large-scale datasets in special education research", International Review of Research in Developmental Disabilities, Vol. 45, Elsevier, Amsterdam, Netherlands, 2013, pp. 155-183. doi:10.1016/B978-0-12-407760-7.00004-9

Grimm, P. (2010), "Pretesting a questionnaire", Wiley International Encyclopedia of Marketing, John Wiley \& Sons, Hoboken, NJ, US, 2010. doi:10.1002/9781444316568.wiem02051

Hwang, B.-G., Zhao, X. and Toh, L. P. (2014), "Risk management in small construction projects in Singapore: Status, barriers and impact", International Journal of Project Management, Vol. 32 No. 1, pp.116-124. doi:10.1016/j.ijproman.2013.01.007.

Hwang, B. G. and Tan, J. S. (2012), "Green building project management: Obstacles and solutions for sustainable development", Sustainable Development, Vol. 20 No. 5, pp.335-349. doi:10.1002/sd.492.

Ilhan, B. and Yaman, H. (2016), "Green building assessment tool (GBAT) for integrated BIM-based design decisions", Automation in Construction, Vol. 70, pp.26-37. doi:10.1016/j.autcon.2016.05.001.

Jalaei, F. and Jrade, A. (2014), "Integrating BIM with green building certification system, energy analysis, and cost estimating tools to conceptually design sustainable buildings", 2014 Construction Research Congress: Construction in a Global Network, 19-21 May 2014, Georgia, US. 140-149. Available from: https://ascelibrary.org/doi/10.1061/9780784413517.015, Last Access: 17 August 2021.

Jalaei, F. and Jrade, A. (2015), "Integrating building information modeling (BIM) and LEED system at the conceptual design stage of sustainable buildings", Sustainable Cities and Society, Vol. 18, pp.95-107. doi:10.1016/j.scs.2015.06.007. 
Johnson, R. B. and Onwuegbuzie, A. J. (2004), "Mixed methods research: A research paradigm whose time has come", Educational Researcher, Vol. 33 No. 7, pp.14-26. doi:10.3102/0013189X033007014.

Kalton, G. and Graham, K. (1983), Introduction to survey sampling, Thousand Oaks, CA, US, Sage Publications. ISBN: 0803921268.

Kansal, R. and Kadambari, G. (2010), "Green buildings: An assessment of life cycle cost", IUP Journal of Infrastructure, Vol. 8 No. 4, Available from: https://ssrn.com/abstract=1759029, Last Access: 17 August 2021.

Kato, H., Too, L. and Rask, A. (2009), "Occupier perceptions of green workplace environment: The Australian experience", Journal of Corporate Real Estate, Vol. 11 No. 3, pp.183-195. doi:10.1108/14630010910985931.

Kavishe, N., Jefferson, I. and Chileshe, N. (2018), "Evaluating issues and outcomes associated with public-private partnership housing project delivery: Tanzanian practitioners' preliminary observations", International Journal of Construction Management, pp.1-16. doi:10.1080/15623599.2018.1435154.

King, A. (2017), "All's well in green buildings", Available from: https://search.informit.org/doi/epdf/10.3316/informit.750329563356391, Last Access: 7 August 2020.

Krishnamurti, R., Biswas, T. and Wang, T.-H. (2010), "Soft tools for sustainable design: Sustainability information framework", From Napkin to BIM. Available from: https://www.andrew.cmu.edu/user/ramesh/pub/distribution/working/SoftTools-Draft.pdf, Last Access: 10 August 2020.

Krivokapic-Skoko, B. and O'neill, G. (2011), "Beyond the qualitative-quantitative distinction: Some innovative methods for business and management research", International Journal of Multiple Research Approaches, Vol. 5 No. 3, pp.290-300. doi:10.5172/mra.2011.5.3.290.

LabCE. (2019), "Acceptable standard deviation (SD)", Available from: https://www.labce.com/spg49741_acceptable_standard_deviation_sd.aspx, Last Access: 7 August 2020.

Lam, P. T., Chan, E. H., Chau, C., Poon, C. and Chun, K. (2009), "Integrating green specifications in construction and overcoming barriers in their use", Journal of Professional Issues in Engineering Education and Practice, Vol. 135 No. 4, pp.142-152. doi:10.1061/(ASCE)10523928(2009)135:4(142).

Lu, Y., Wu, Z., Chang, R. and Li, Y. (2017), "Building information modeling (BIM) for green buildings: A critical review and future directions", Automation in Construction, Vol. 83, pp.134-148. doi:10.1016/j.autcon.2017.08.024.

Manu, P., Mahamadu, A.-M., Booth, C., Olomolaiye, P., Ibrahim, A. D. and Coker, A. (2018), "Assessment of procurement capacity challenges inhibiting public infrastructure procurement: A Nigerian inquiry", Built Environment Project and Asset Management, Vol. 8 No. 4, pp.386402. doi:10.1108/BEPAM-02-2018-0038.

MBIE. (2017), "Small business in New Zealand: How do they compare with large firms?", Available from: $\quad$ https://www.beehive.govt.nz/sites/default/files/2017-12/Small\%20Business\%20\%20Annex\%203\%20Small\%20Business\%20Factsheet.pdf, Last Access: 7 August 2020.

MED. (2011), "SMEs in New Zealand: Structure and dynamics 2011", Available from: http://workspace.unpan.org/sites/internet/Documents/UNPAN92674.pdf, Last Access: 7 August 2020.

Morris, A., Zuo, J., Wang, Y. and Wang, J. (2018), "Readiness for sustainable community: A case study of Green Star Communities", Journal of Cleaner Production, Vol. 173, pp.308-317. doi:10.1016/j.jclepro.2017.03.190.

Motawa, I. and Carter, K. (2013), "Sustainable BIM-based evaluation of buildings", Procedia-Social and Behavioral Sciences, Vol. 74, pp.419-428. doi:10.1016/j.sbspro.2013.03.015.

Ng, S. T., Chen, Y. and Wong, J. M. W. (2013), "Variability of building environmental assessment tools on evaluating carbon emissions", Environmental Impact Assessment Review, Vol. 38, pp.131-141. doi:10.1016/j.eiar.2012.07.003. 
Nguyen, T., Toroghi, S. H. and Jacobs, F. (2015), "Automated green building rating system for building designs", Journal of Architectural Engineering, Vol. 22 No. 4, pp.A4015001. doi:10.1061/(ASCE)AE.1943-5568.0000168.

NZGBC. (2016), "Green Star technical manual v3.1", Available from: https://www.nzgbc.org.nz/Attachment?Action=Download\&Attachment_id=694, Last Access: 7 August 2020

NZGBC. (2020), "Green Star", Available from: https://www.nzgbc.org.nz/GreenStar, Last Access: 17 August 2021.

NZGBC. (2021), "Home page", Available from: https://www.nzgbc.org.nz/, Last Access: 17 August 2021.

Oke, A. E. and Aghimien, D. O. (2018), "Drivers of value management in the Nigerian construction industry", Journal of Engineering, Design and Technology, Vol. 16 No. 2, pp.270-284. doi:10.1108/JEDT-02-2017-0012.

Onwuegbuzie, A. J. and Leech, N. L. (2005), "On becoming a pragmatic researcher: The importance of combining quantitative and qualitative research methodologies", International Journal of Social Research Methodology, Vol. 8 No. 5, pp.375-387. doi:10.1080/13645570500402447.

Owusu-Manu, D.-G., Edwards, D. J., Kukah, A., Parn, E. A., El-Gohary, H. and Hosseini, M. R. (2018), "An empirical examination of moral hazards and adverse selection on PPP projects: A case study of Ghana", Journal of Engineering, Design and Technology, Vol. 16 No. 6, pp.910-924. doi:10.1108/JEDT-01-2018-0001.

Park, J., Park, J., Kim, J. and Kim, J. (2012), "Building information modelling based energy performance assessment system: An assessment of the Energy Performance Index in Korea", Construction Innovation, Vol. 12 No. 3, pp.335-354. doi:10.1108/14714171211244587.

Pilechiha, P., Mahdavinejad, M., Pour Rahimian, F., Carnemolla, P. and Seyedzadeh, S. (2020), "Multiobjective optimisation framework for designing office windows: quality of view, daylight and energy efficiency", Applied Energy, Vol. 261, pp.114356. doi:10.1016/j.apenergy.2019.114356.

Rasheed, E., Byrd, H., Money, B., Mbachu, J. and Egbelakin, T. (2017), "Why are naturally ventilated office spaces not popular in New Zealand?", Sustainability, Vol. 9 No. 6, pp.902. doi:10.3390/su9060902.

Rehm, M. and Ade, R. (2013), "Construction costs comparison between 'green'and conventional office buildings", Building Research \& Information, Vol. 41 No. 2, pp.198-208. doi:10.1080/09613218.2013.769145.

Revilla, M. A., Saris, W. E. and Krosnick, J. A. (2014), "Choosing the number of categories in agreedisagree scales", Sociological Methods \& Research, Vol. 43 No. 1, pp.73-97.

Robert, O. K., Dansoh, A. and Ofori-Kuragu, J. K. (2014), "Reasons for adopting public-private partnership (PPP) for construction projects in Ghana", International Journal of Construction Management, Vol. 14 No. 4, pp.227-238. doi:10.1080/15623599.2014.967925.

Ross, A. and Willson, V. L. (2018), Basic and advanced statistical tests: Writing results sections and creating tables and figures, Berlin, Germany, Springer. ISBN: 9463510869.

Samari, M., Ghodrati, N., Esmaeilifar, R., Olfat, P. and Shafiei, M. W. M. (2013), "The investigation of the barriers in developing green building in Malaysia", Modern Applied Science, Vol. 7 No. 2, pp.1. doi:10.5539/mas.v7n2p1.

Schneider, T. and Wheeler-Kingshott, C. A. (2014), "Q-space imaging: A model-free approach", Quantitative MRI of the Spinal Cord, Elsevier, Amsterdam, Netherlands, 2014, pp. 146-155. doi:10.1016/B978-0-12-396973-6.00010-1

Seghier, T. E., Ahmad, M. H., Wah, L. Y. and Samuel, W. O. (2018), "Integration models of building information modelling and green building rating systems: A review", Advanced Science Letters, Vol. 24 No. 6, pp.4121-4125. doi:10.1166/asl.2018.11554.

Seyedzadeh, S., Pour Rahimian, F., Oliver, S., Rodriguez, S. and Glesk, I. (2020a), "Machine learning modelling for predicting non-domestic buildings energy performance: A model to support deep energy retrofit decision-making", Applied Energy, Vol. 279, pp.115908. doi:10.1016/j.apenergy.2020.115908. 
Seyedzadeh, S., Rahimian, F. P., Oliver, S., Glesk, I. and Kumar, B. (2020b), "Data driven model improved by multi-objective optimisation for prediction of building energy loads", Automation in Construction, Vol. 116, pp.103188. doi:10.1016/j.autcon.2020.103188.

Siddiqui, M. Z., Pearce, A. R., Ku, K., Langar, S., Ahn, Y. H. and Jacocks, K. (2009), "Green BIM approaches to architectural design for increased sustainability", International Conference on Construction Engineering and Project Management (ICCEM-ICCPM), 27-30 May 2009, Jeju, Korea. Available from: https://www.researchgate.net/publication/236878118_Green_BIM_Approaches_to_Architect ural_Design_for_Increased_Sustainability, Last Access: 17 August 2021.

Sieber, S. D. (1973), "The integration of fieldwork and survey methods", American Journal of Sociology, Vol. 78 No. 6, pp.1335-1359. Available from: https://www.jstor.org/stable/2776390, Last Access: 17 August 2021.

Suzer, O. (2015), "A comparative review of environmental concern prioritization: LEED vs other major certification systems", Journal of Environmental Management, Vol. 154, pp.266-283. doi:10.1016/j.jenvman.2015.02.029.

Teddlie, C. and Yu, F. (2007), "Mixed methods sampling: A typology with examples", Journal of Mixed Methods Research, Vol. 1 No. 1, pp.77-100. doi:10.1177/1558689806292430.

Vierra, S. (2016), "Green building standards and certification systems", Available from: https://www.wbdg.org/resources/green-building-standards-and-certification-systems, Last Access: 17 August 2021.

Wheeler, A. R., Shanine, K. K., Leon, M. R. and Whitman, M. V. (2014), "Student-recruited samples in organizational research: A review, analysis, and guidelines for future research", Journal of Occupational and Organizational Psychology, Vol. 87 No. 1, pp.1-26. doi:10.1111/joop.12042.

Williams, K. and Dair, C. (2007), "What is stopping sustainable building in England? Barriers experienced by stakeholders in delivering sustainable developments", Sustainable Development, Vol. 15 No. 3, pp.135-147. doi:10.1002/sd.308.

Wong, J. K.-W. and Kuan, K.-L. (2014), "Implementing 'BEAM Plus' for BIM-based sustainability analysis", Automation in Construction, Vol. 44, pp.163-175. doi:10.1016/j.autcon.2014.04.003.

Wu, W. and Issa, R. R. (2014), "BIM execution planning in green building projects: LEED as a use case", Journal of Management in Engineering, Vol. 31 No. 1, pp.A4014007. doi:10.1061/(ASCE)ME.1943-5479.0000314.

Ying Liu, J., Pheng Low, S. and He, X. (2012), "Green practices in the Chinese building industry: Drivers and impediments", Journal of Technology Management in China, Vol. 7 No. 1, pp.5063. doi:10.1108/17468771211207349.

Zhang, L., Wu, J. and Liu, H. (2018), "Turning green into gold: A review on the economics of green buildings", Journal of Cleaner Production, Vol. 172, pp.2234-2245. doi:10.1016/j.jclepro.2017.11.188.

Zuo, J. and Zhao, Z.-Y. (2014), "Green building research-current status and future agenda: A review", Renewable and Sustainable Energy Reviews, Vol. 30, pp.271-281. doi:10.1016/j.rser.2013.10.021. 